\title{
O ARGUMENTO DO VALOR INTRÍNSECO DA VIDA HUMANA CONTRA A MORTE DE EMBRIÕES HUMANOS
}

\author{
THE ARGUMENT OF THE INTRINSIC VALUE OF HUMAN LIFE AGAINST \\ THE KILLING OF HUMAN EMBRYOS
}

\author{
LINCOLN FRIAS ${ }^{1}$ \\ (Unifenas, NEPC-UFMG, FAPEMIG / Brasil)
}

\begin{abstract}
RESUMO
Normalmente se argumenta contra o descarte de embriões humanos defendendo a atribuição de direito à vida a eles. No entanto, os argumentos apresentados com esse intuito não têm sido bem sucedidos. Uma alternativa é dizer que o erro moral em matar embriões humanos é desrespeitar o valor intrínseco da vida humana. Esse artigo apresenta essa proposta e aponta suas deficiências. A conclusão é que, caso a vida dos embriões humanos contenham algum tipo de valor intrínseco, ele é insignificante porque não é específico da vida humana, não é o que torna errado matar pessoas adultas e porque ele seria muito pequeno, dadas as especificidades do embrião.
\end{abstract}

Palavras-chave: Valor intrínseco. Vida humana. Embriões humanos. Ética aplicada.

\begin{abstract}
The argument against the disposal of human embryos is usually made defending the attribution of a right to life to them. However, the attempts made in this direction have not been successful. An alternative to it is to say that what is morally wrong in killing human embryos is the disregard of the intrinsic value of life. This article presents this proposal and points out its flaws. The conclusion is that, if the life of human embryos contain some kind of intrinsic value, it is negligible because it is not specific of the human life, it is not what makes it wrong to kill adults and because it would be very small, given the particularities of the embryo.
\end{abstract}

Keywords: Intrinsic value. Human life. Human embryos. Applied ethics.

As células-tronco embrionárias são uma das grandes promessas científicas da nossa época. Sua capacidade de se transformar em qualquer dos tecidos do corpo humano adulto pode ajudar a tratar desde a paraplegia e a cegueira até o mal de Alzheimer. No entanto, para chegar até lá é preciso usar embriões humanos para derivá-las, o que pode significar sua morte (rigorosamente falando, eles continuam vivos, mas sob a forma de células individuais). Outra tecnologia, a fertilização in vitro usando diagnóstico genético pré-implantação, permite que casais inférteis ou que possuam sérias doenças genéticas possam ter filhos saudáveis, mas isso ao preço de criar embriões excedentes que morrerão no processo.

O rebuliço criado pelo julgamento da Ação Direta de Inconstitucionalidade 3.510 pelo Supremo Tribunal Federal brasileiro em 2008 deu uma amostra da controvérsia que o uso e ethic@-Florianópolis, v. 11, n.3,p.239-259. Dez.2012. 
descartes de embriões humanos pode gerar. Uma parte significativa da opinião pública se colocou contra essa utilização, o que gerou uma discussão que foi mais ampla do que a oposição entre religião e ciência.

A maioria dos argumentos não-religiosos contra o descarte de embriões humanos baseiase na idéia de que matar o embrião é prejudicá-lo porque ofende seu direito à vida. Por isso, o objetivo dos argumentos é mostrar que o embrião possui direito à vida. O Argumento da Individualidade Genética diz que todo embrião tem direito à vida na medida em que tem um patrimônio genético único. O Argumento da Continuidade diz que se os recém-nascidos têm direito à vida os embriões também o têm, pois não há um momento de ruptura entre a fertilização e o nascimento. O Argumento do Pertencimento à Espécie Humana diz que os embriões têm direito à vida porque são seres humanos. O Argumento da Potencialidade diz que se todas as pessoas têm direito à vida, os embriões também o têm já que possuem o potencial para se tornar pessoas (BROWN, 2007; LIZZA, 2007; HARMAN, 2003; HOLLAND, 2003). O Argumento do Futuro de Valor diz que se o que torna errado matar uma pessoa adulta é o fato de que isso vai impedir que ela viva seu futuro, isso também se aplica aos embriões e, portanto, eles também têm direito à vida (MARQUIS, 1989, 2007a).

Esses argumentos têm méritos distintos. Mas embora alguns sejam mais sólidos do que outros, todos têm suas deficiências e há motivos para considerá-los insuficientes (FRIAS, 2010; BOONIN, 2003; MCMAHAN, 2002). Os embriões são muito diferentes dos seres a que atribuímos direitos. Como eles não possuem nem a capacidade de sentir dor nem a capacidade de agir intencionalmente, não parece justificável atribuir-lhes direitos que protejam seus interesses, pois não é claro que eles realmente possuam interesses no sentido que as pessoas possuem.

O Argumento do Valor Intrínseco da Vida Humana é uma estratégia diferente que o concepcionista (aquele que defende que os embriões têm direito à vida desde a concepção) pode adotar para defender que é errado matar embriões. Ao contrário dos precedentes, esse argumento não afirma que o embrião é prejudicado nem que ele tem direito à vida. O que ele afirma é que matar embriões é errado porque a vida humana tem valor em si, em qualquer forma ou grau de desenvolvimento.

A formulação mais detalhada desse argumento é a de (DWORKIN, 1993). Entretanto, ele a faz em termos de sacralidade, o que despertou várias críticas. p. ex., de acordo com (MCMAHAN, 2002, p. 333), a posição dos religiosos não é a pintada por Dworkin (tomando a 
sacralidade como sinônimo de valor intrínseco). Ao falar em sacralidade, um religioso pode querer dizer que matar o embrião é contra a vontade de Deus ou é interferir em seu domínio, quer dizer, não temos a autoridade para acabar com uma vida (porque somos sua propriedade ou que ele tem propósitos para nossas vidas). Além disso, a sacralidade pode ser entendida como não admitindo graus, ela é inviolável, ao contrário do que supõe Dworkin. Para contornar essas dificuldades, é melhor falar em valor intrínseco ao invés de sacralidade.

O Argumento do Valor Intrínseco da Vida Humana é adequado para quem é contra o descarte de embriões, mas que admite que não faz sentido falar de direitos e interesses dos embriões, pois para ter interesses é preciso ter consciência e para tê-la é preciso ter cérebro, e o embrião está muito longe de tê-lo. Além disso, muitos concepcionistas consideram morais os abortos feitos em casos de estupro, incesto, risco de vida para a mãe ou malformações congênitas incompatíveis com a vida, o que é inconsistente com a crença de que o feto possui direito à vida, pois nesses casos o feto também o teria. Mas acreditar que a vida humana tem valor intrínseco é compatível com a aceitação do aborto nesses casos, com a aceitação de que o embrião não tem interesses e com a convicção de que deve ser proibido matar embriões. O que essa crença implica é apenas que sempre se tome a decisão que demonstre mais respeito pela vida humana.

Esse artigo pretende apresentar o Argumento do Valor Intrínseco e apontar suas principais falhas. Ele está organizado da seguinte maneira: a próxima seção tenta dar mais clareza à ideia de que a vida humana tem um valor intrínseco ou impessoal, diferenciando-o dos valores pessoal e instrumental. A segunda seção discute o problema de delimitar qual é o valor impessoal quando o pessoal e o instrumental são nulos, o que é feito através de uma comparação com o valor intrínseco da vida de animais não-humanos. A terceira sessão trata do problema de delimitar quais vidas possuem mais valor intrínseco, em outras palavras, quando a morte é pior. Ela faz isso confrontando uma Resposta Simples a uma Resposta Complexa a esse problema. Em seguida, partindo da Resposta Complexa, pergunta-se qual o peso que o valor intrínseco à vida do embrião teria na decisão de utilizá-lo ou não para derivar células-tronco e na fertilização in vitro. $\mathrm{Na}$ última sessão antes da conclusão, é feita uma crítica do Argumento do Valor Intrínseco a partir da questão de porque é errado matar uma pessoa adulta. 


\section{O valor intrínseco da vida humana}

A decisão da Suprema Corte dos Estados Unidos em um caso sobre eutanásia, conhecido como Cruzan contra Diretor da Secretaria de Saúde de Missouri, ilustra de maneira clara a força moral que a crença no valor intrínseco da vida pode ter. Nancy Cruzan era uma jovem que ficou em estado vegetativo persistente por causa de um acidente automobilístico. Como ela não tinha chances de ter sua saúde restabelecida, seus pais pediram a retirada dos tubos de alimentação e nutrição artificiais dos quais ela dependia para se manter viva e que se permitisse que ela morresse. Contrariando a vontade dos pais, porém, os promotores impetraram uma ação exigindo que o hospital não atendesse ao pedido dos pais, alegando que o estado do Missouri tinha o direito e o dever de manter a moça viva por respeito ao valor intrínseco da vida. Os pais levaram a ação até a Suprema Corte que não só a confirmou, como ampliou a decisão do tribunal estadual. A sentença afirmou que a comunidade do Missouri tinha razões para manter Nancy viva mesmo que isso fosse contrário aos interesses dela, pois o Estado pode considerar que é intrinsecamente mau alguém morrer deliberada e prematuramente. O voto de outro juiz, Antonin Scalia, afirmou explicitamente que o Valor Intrínseco não depende dos direitos ou interesses dos indivíduos. Por isso, segundo ele, o Estado pode até mesmo impedir o suicídio de pessoas que consideram que morrer seria melhor para elas (DWORKIN, 1993, p. 12 - o capítulo 7 desse livro consiste em uma análise detalhada dessa sentença). Essa é a fundamentação da idéia de que as pessoas não têm o direito de morrer (deliberadamente), pois a vida humana é um bem em si, impessoal.

A vida humana pode ter três tipos de valor (DWORKIN, 1993, p. 67-108). Ela tem valor pessoal (ou subjetivo) na medida em que é uma coisa boa para a pessoa que a possui. Nesse sentido, por exemplo, a vida do ex-presidente Lula tem valor na medida em que estar vivo é bom para ele, Luis Inácio Lula da Silva. Estar vivo pode deixar de ser bom para ele, talvez porque seus sonhos se tornem impossíveis ou porque a quantidade de sofrimento se torne insuportável. Isso faria com que a vida dele não tivesse mais valor pessoal.

A vida do Lula pode ter um segundo tipo de valor, que independe do valor pessoal. A vida humana tem valor instrumental quando contribui para o bem estar de outros. Nesse sentido, o fato de que o ex-presidente continue vivo é bom na medida em que contribui para a vida de outras pessoas. Não importa que a vida dele se torne uma desilusão ou que tenha mais sofrimento do que prazer, ela continua sendo valiosa na medida em que ajude os outros, mesmo que viver 
tenha deixado de ser bom para ele. Entretanto, se o fato de ele estar vivo deixar de contribuir positivamente para a vida dos outros, ela não terá mais valor instrumental.

Se a vida do Presidente não tiver mais valor pessoal nem valor instrumental, se estar vivo deixar de ser bom para ele e o fato de ele estar vivo não beneficiar mais ninguém, isso significa que a vida dele perdeu todo o seu valor?

Não, caso se considere que a vida humana tenha valor intrínseco (ou impessoal), que é o caso quando algo é bom independentemente de contribuir para o bem estar de alguém. ${ }^{2}$ Dworkin (1993, p. 76) oferece como exemplo de coisas que têm valor intrínseco as obras de arte, o conhecimento, as espécies biológicas e as culturas humanas. Mesmo que a destruição delas seja instrumentalmente ruim, ela também é ruim impessoalmente, porque algo maravilhoso foi aniquilado para sempre. O fato de que uma espécie biológica seja extinta é uma tragédia mesmo que ela não tenha valor científico, terapêutico ou recreativo (certamente, a tragédia será maior quanto mais desses valores ela tiver, mas isso mostra apenas que o valor instrumental pode ser adicionado ao intrínseco).

Segundo Dworkin, há dois tipos de objetos com valor intrínseco (DWORKIN, 1993, p. 75). O tipo incremental é aquele tipo de objeto que seria desejável que existisse em maior quantidade, por exemplo, o conhecimento (quanto mais conhecimento melhor, mesmo que ele seja inútil). O outro tipo é o valor intrínseco não-incremental, aquele possuído por objetos que são valiosos porque, e apenas quando, existem. $\mathrm{O}$ fato de que espécies biológicas tenham valor intrínseco não faz com que seja desejável criar espécies artificiais só para que existam mais espécies (embora certamente seja desejável criar novas espécies que tenham valor instrumental). O valor intrínseco da vida humana é deste segundo tipo, pois o fato de que a vida humana seja valiosa não faz com que seja desejável que se crie tantas vidas humanas quanto for possível. Entretanto, depois de iniciada determinada vida humana, é muito importante que ela não se perca (DWORKIN, 1993, p. 74).

O que confere valor intrínseco à vida humana? Várias razões costumam ser apontadas como resposta: apenas seres humanos têm almas; seres humanos são preferidos por Deus; apenas seres humanos possuem capacidades cognitivas e emocionais superiores; as vidas humanas são feitas de experiências e atividades que são intrinsecamente boas (e é melhor impessoalmente que exista mais prazer no mundo); a complexidade biológica do organismo humano, especialmente a de seu cérebro etc. 
Entretanto, todas essas razões são bastante controversas - p.ex., não há como provar a existência de almas e o cérebro dos golfinhos é mais complexo que os nossos sob alguns aspectos. Por isso, Dworkin oferece uma resposta que procura tangenciar as controvérsias, com a virtude de manter o núcleo dessas razões. Segundo ele, há duas maneiras pelas quais algo pode adquirir valor impessoal: por associação ou por sua história. O primeiro processo é aquele em que, p.ex., uma bandeira adquire valor intrínseco porque está associada à nação. O segundo processo é aquele em que algo adquire valor impessoal porque veio a existir através de investimento natural (ou divino, para os religiosos) ou humano. Esse processo é o que torna valiosas as espécies naturais e as obras de arte, já que seu valor deriva do fato de que consideramos importantes e admiráveis os processos que as criaram. Seria uma vergonha que atos e decisões humanas destruíssem algo que surgiu de um processo criativo que exigiu tanta energia (DWORKIN, 1993, p. 76-77).

A vida humana tem valor intrínseco porque surgiu de um processo que recebeu tanto investimento natural quanto investimento humano. Considera-se sumamente importante que a espécie humana não apenas sobreviva biologicamente, mas que ela prospere culturalmente. A preocupação da humanidade não é apenas com quem está vivo ou com os filhos de quem está vivo, mas com todas as gerações que virão. Por isso, todo o esforço de articulação em torno das mudanças climáticas não pode ser explicado apenas através de uma discussão sobre os direitos e os interesses das pessoas futuras. Trata-se da premissa tácita e básica de que a espécie humana deve sobreviver e prosperar. Esse é o conteúdo e a explicação da idéia de que a vida humana tem valor intrínseco.

Mas a vida humana não tem valor intrínseco apenas quando considerada em geral, cada vida humana possui em si esse valor. A vida humana tem valor intrínseco não-instrumental porque, especialmente quando o indivíduo ainda é uma criança, ele exige muito investimento criativo das pessoas que estão à sua volta e, em um sentido mais indireto, dos processos evolutivos e das gerações que o antecederam e criaram a comunidade, a língua e a tecnologia que deram forma à sua vida. Além disso, quando as capacidades cognitivas se desenvolvem o próprio indivíduo começa a se fazer, em um processo misterioso pelo qual todos têm que passar. Por causa das escolhas que cada um precisa fazer durante sua vida, em certa medida, cada pessoa é sua própria criação. As angústias e prazeres que esse desafio cria em todos desperta a empatia, indicando que todos compartilham uma mesma condição assustadora (DWORKIN, 1993, p. 82- 
84). É a perda intencional do investimento feito pelo indivíduo e por outros em prol dele diante desse desafio que é sentida quando uma vida se perde, mesmo que ela não tenha valor pessoal ou instrumental.

Embora Dworkin tenha recebido muitas críticas pela imprecisão da noção de valor intrínseco não incremental, é difícil discordar da idéia de que a vida humana tem um valor impessoal, independente da utilidade que ela possa ter para quem a possui ou para outras pessoas. Talvez essa idéia derive simplesmente de alguma intuição instintiva que tenha tido papel evolutivo, ou seja, apenas expressão de parcialidade injustificada pela própria espécie, casos em que seria apenas uma irracionalidade. Mas, de qualquer maneira, o apelo ao Valor Intrínseco desempenha tal papel de destaque no debate público que dar-lhe uma resposta seria muito proveitoso.

O uso que o concepcionista faz do Argumento do Valor Intrínseco é: se a vida humana tem valor intrínseco, o que desrespeitar esse valor é moralmente errado; ora, supostamente, matar embriões desrespeita o Valor Intrínseco; logo, matar embriões é moralmente errado. Como esse argumento pode ser respondido?

Os embriões em questão na fertilização in vitro e na derivação de células-tronco embrionárias, não têm valor instrumental nem valor pessoal. Quando se fala da morte de embriões em laboratório, trata-se de embriões criados para tratamentos de infertilidade ou criados especialmente para pesquisa científica. Só têm valor instrumental para tratamento de infertilidade aqueles embriões que forem escolhidos para serem implantados. Os embriões criados para tratamento, mas que não foram escolhidos (embriões excedentes ou supranumerários), não têm valor instrumental, pois não é do interesse de nenhuma pessoa que eles sejam implantados. Entretanto, eles podem ser utilizados para pesquisa. Nesse caso, porém, juntamente com os embriões criados especialmente para pesquisas científicas, eles não têm valor instrumental se forem mantidos vivos, pelo contrário, seu valor instrumental só pode se realizar se eles puderem ser descartados. Portanto, embriões que interessam à discussão sobre fertilização in vitro e à derivação de células-tronco não têm valor instrumental a não ser se puderem ser descartados.

Por não terem nem os rudimentos de um sistema nervoso antes do $14^{\circ}$ dia após a gestação, que é quando são utilizados pelas tecnologias em questão, a vida deles também não tem valor pessoal, nada em sua vida presente tem valor para eles. Qualquer interesse que tenha é do 
mesmo tipo que microorganismos têm em continuarem vivos, que certamente são extremamente fracos se comparados ao de pessoas.

De modo que, para garantir que sua vida tenha valor, só lhes resta o valor impessoal. Qual a força da objeção a matar embriões colocada pelo valor impessoal ou intrínseco? Em que medida o valor intrínseco da vida dos embriões justifica que seja errado matá-los? Colocada de maneira precisa, a questão é: qual é o valor impessoal quando o pessoal e o instrumental são nulos?

\section{Qual é o valor impessoal quando o pessoal e o instrumental são nulos?}

Um modo de esclarecer a magnitude desse valor é compará-lo com algo semelhante, ao qual normalmente se atribui quase nenhum valor: um animal não-humano. $\mathrm{O}$ valor impessoal da morte do embrião precisa ser muito maior do que o valor impessoal que é perdido com a morte de um animal não-humano, porque senão a morte do animal deveria ser considerada tão ofensiva ao valor intrínseco da vida em geral quanto a do embrião - suponho aqui que não haja uma boa justificativa para ser parcial em relação à espécie humana a não ser as características cognitivas como autonomia, autoconsciência e racionalidade. Por ter uma vida psicológica muito mais rica, a morte de um ser humano adulto típico é uma perda de valor impessoal muito maior do que a de um animal não-humano. A vida mental do embrião, entretanto, é inferior à de qualquer animal adulto não-humano; por isso, sua vida não tem experiências mais valiosas do que a deles e, no momento, ele não é biologicamente mais complexo do que um animal (MCMAHAN, 2002, p. 317-329). Não há maior investimento natural na vida de um embrião do que na de um animal adulto, nem necessariamente mais investimento humano (um animal doméstico treinado recebeu mais atenção do que um embrião). Se há investimento divino, não há muita razão para supor que Deus investiu mais no embrião do que em um animal adulto - se houvesse alguma razão sólida para acreditarmos que apenas seres humanos possuem alma isso seria diferente, mas não há.

O fato de pertencer à espécie humana também não pode ser a razão de porque o valor impessoal da morte dos embriões supera em muito a dos animais, pois isso seria uma parcialidade injustificada, a diferença biológica não marca necessariamente uma diferença moral. $\mathrm{O}$ que distingue a vida humana embrionária da de outros animais é que ela tem o potencial para se tornar pessoa, mas ter o potencial não é o mesmo que ter a característica efetivada, animais não- 
humanos e seres humanos devem ser comparados segundo as características que possuem no momento da ação de matar, infligir sofrimento etc. Além disso, não há nada de valioso impessoalmente, independente do valor para o embrião ou para outros, no desenvolvimento da potencialidade do embrião, que o distinga dos outros animais. Se o que tem valor impessoal for a existência de uma nova pessoa no mundo, então a potencialidade teria apenas valor instrumental em criar o que terá valor impessoal. Por isso, afirmações sobre o valor intrínseco do potencial do embrião parecem afirmações distorcidas sobre o valor intrínseco das propriedades que o embrião terá caso se transforme em uma pessoa. É o velho erro de tratar a pessoa potencial como se já existisse secretamente no embrião. O potencial sozinho tem apenas valor instrumental, apenas se ele for realizado é que terá valor impessoal (MCMAHAN, 2002, p. 334-336).

Suponha que isso esteja errado e que o potencial do embrião humano tenha sim valor impessoal. Mesmo assim, não se justifica que toda vida humana, em qualquer forma, tenha valor intrínseco. Se toda vida humana possuir valor intrínseco porque a potencialidade para ser pessoa tem valor impessoal, então todo ser humano deve ter esse potencial e poucos, ou nenhum, animal não-humano devem ter. Se os animais não-humanos podem ou não ser pessoas é uma questão extremamente controversa, mas sabe-se indubitavelmente que nem todo ser humano tem potencial para ser pessoa. O caso mais claro é o dos fetos anencéfalos (MCMAHAN, 2002, p. 336; BIRCHAL; FRIAS, 2009;). Logo, se algo dá a todos os seres humanos valor intrínseco e não aos animais, isso não pode ser o potencial para se tornar pessoa, pois fetos anencéfalos são humanos e não têm potencial para se transformar em pessoas. Então, ou nem toda vida humana tem valor intrínseco ou não é a potencialidade que confere esse valor à vida humana. Contudo, se não for a potencialidade, não há outro candidato aceitável.

Portanto, não há nada que mostre que o embrião tem muito mais valor impessoal do que um animal não-humano adulto, especialmente os mamíferos. Sua vida psicológica não é superior, não se pode afirmar que os investimentos natural, humano e divino sejam muito diferentes, não é legítimo tratar a espécie como moralmente significativa e a potencialidade não é suficiente para diferenciar os casos. A conclusão é que o embrião tem pouco ou nenhum valor impessoal.

Como muita gente acredita que o embrião tenha valor impessoal, suponhamos que isso seja verdade, apenas para verificar até onde isso leva o argumento. O fato de que embriões tenham valor intrínseco poderia justificar uma objeção forte a matá-los (MCMAHAN, 2002, p. 336)? 


\section{A ruindade da morte: a resposta simples e a resposta complexa}

Quem usa esse argumento normalmente supõe que, uma vez que se admita que a vida humana tenha valor intrínseco, a conclusão de que não deve ser permitido que embriões sejam mortos segue-se implacavelmente. Entretanto, é possível compatibilizar a idéia de valor intrínseco com a possibilidade de se matar embriões para pesquisa e reprodução. A chave para fazer isso é reconhecer que nem toda perda de vida humana ofende igualmente seu valor intrínseco, há uma “métrica do desrespeito" (DWORKIN, 1993, p. 84-89).

Há graus de gravidade na perda de uma vida humana. Por exemplo, tudo o mais permanecendo igual, a perda da vida de um jovem é considerada mais trágica do que a de um idoso, a morte de uma pessoa emocionalmente saudável mais trágica do que a de um suicida, a de um pai de família mais do que a de um solteiro. A questão não é que seja aceitável matar ou recusar recursos médicos a um deles e não ao outro, todos têm o mesmo direito. Nesse contexto, não se trata de justiça na microalocação de recursos. Mas sim de como avaliamos e comparamos uma tragédia, o desperdício de vida que ela causa e o insulto ao valor intrínseco da vida.

A Resposta Simples é que a gravidade da tragédia é proporcional à diferença entre a idade em que a pessoa morreu e sua expectativa de vida, pois se supõe que seu futuro conteria mais coisas boas do que ruins. Portanto, quanto mais cedo a pessoa morrer, mais isso ofende o valor intrínseco da vida, pois é provável que quanto mais cedo a pessoa morreu, menos coisas boas ela experimentou e mais coisas boas ela poderia ter experimentado.

Embora tenha plausibilidade, essa resposta é bastante incompleta. A qualidade dos anos de vida por vir não deveria também influenciar no cálculo da ruindade da morte (se a vida era física e psicologicamente limitada ou sofrida)? Não deveria ser computado também o que essa morte representa para outras pessoas (p.ex., o fato de ser um pai de família, empregador ou gênio não conta)?

A incompletude não é o problema mais grave da resposta simples. Seu principal problema é que ela é inconsistente com duas intuições morais centrais e amplamente aceitas. A primeira delas é que a vida não tem valor incremental, não é verdade que quanto mais vidas melhor. Se o que se lamenta foi a vida que poderia ser vivida que se perdeu, a masturbação, o sexual casual, a contracepção e a abstinência sexual deveriam ser lamentados, pois elas também limitam a quantidade de vida vivida que poderia haver ao evitar que nasçam mais pessoas. 
A segunda intuição moral que é inconsistente com a Resposta Simples é a crença de que um aborto tardio é pior do que um aborto inicial. Até mesmo os mais conservadores concordam que o aborto de um feto de sete meses é pior do que o de um feto de dois meses. A Resposta Simples, no entanto, indica que a morte do feto menos desenvolvido é pior, se tudo o mais for mantido igual, porque ele tem cinco meses a mais de vida em expectativa.

O erro da Resposta Simples é se concentrar no que poderá ou não acontecer no futuro e desconsiderar que o que torna a perda de vida maior e mais trágica é o que aconteceu no passado (DWORKIN, 1993, p. 88). Por isso, ela deve ser substituída pela Resposta Complexa, a qual deve dar conta de que, tudo o mais permanecendo igual:

- $\quad$ a morte de um feto de sete meses é pior do que a de um de feto de dois meses.

- $\quad$ a morte de uma criança de três anos é pior do que a de um recém-nascido de um mês.

- $\quad$ a morte de uma adolescente de quinze anos é pior do que a de um bebê de um ano.

- a morte de uma adolescente de vinte anos é pior do que a de uma senhora de oitenta anos.

- $\quad$ entre o começo da adolescência e o início da velhice não é claro se uma morte é pior do que outra.

A ruindade da morte - isto é, o quanto a morte de alguém é ruim - não diminui de modo linear à medida que a idade aumenta. Na Figura 1 a ruindade da morte está apresentada em relação à idade de morte de acordo com a Resposta Simples e de acordo com a Resposta Complexa. A ruindade sobe do nascimento até o final da infância ou início da adolescência, depois se mantêm constante até o começo da meia-idade, para depois descer até a velhice avançada. 


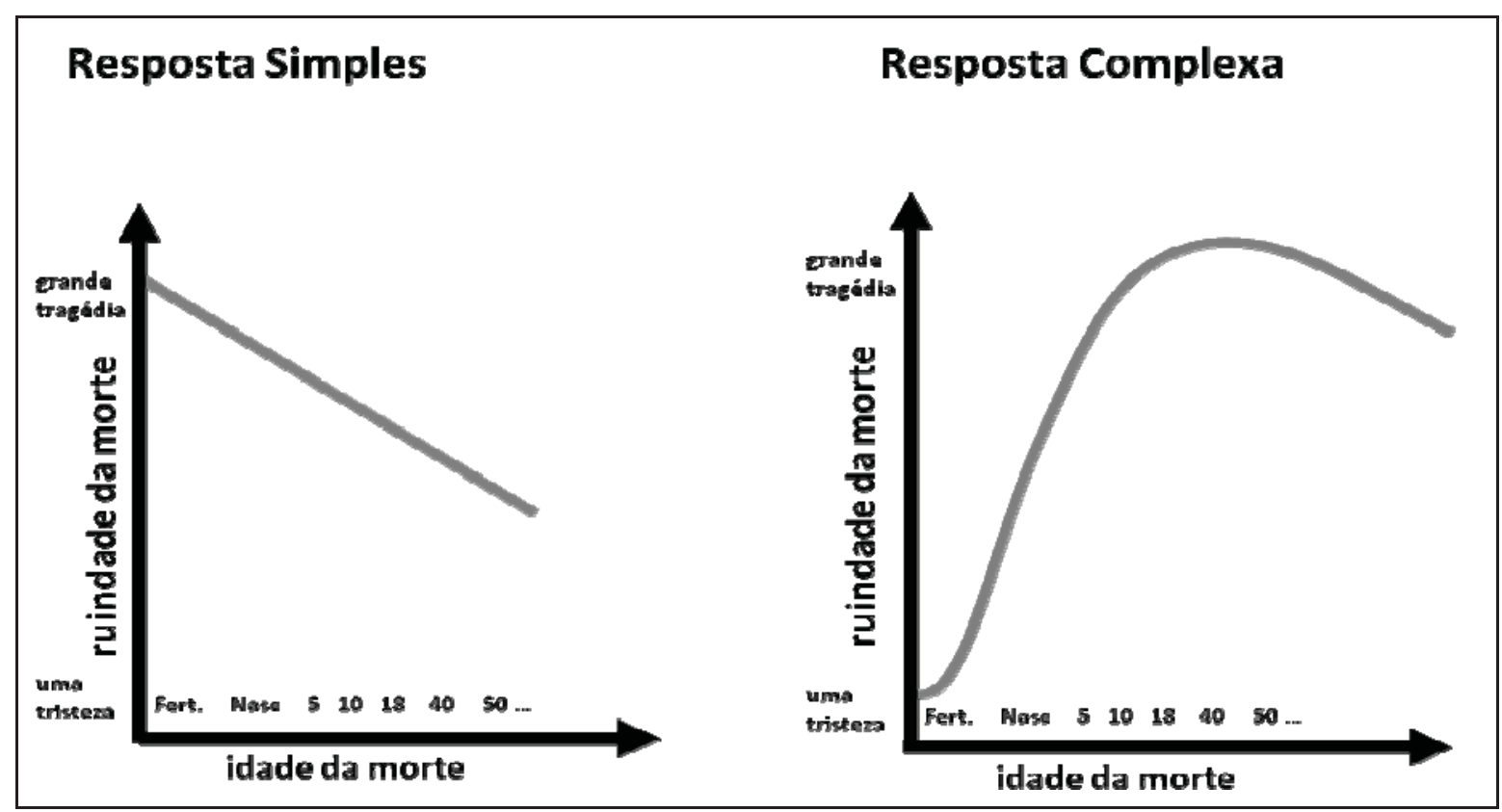

FIGURA 1: Ruindade da morte em relação à idade da morte segundo a Resposta Simples e segundo a Resposta Complexa.

Como diz Dworkin (1993, p. 88), deploramos a frustração da vida e não sua mera ausência. A morte da adolescente é pior que a do bebê porque ela frustra investimentos que ela e outros já haviam feito em sua vida (ambições e expectativas que ela teve, planos, projetos e envolvimento emocional que criou para si e que os outros criaram para ela). A ruindade da morte é maior se a morte ocorrer depois que a própria pessoa tiver feito um investimento pessoal significativo em sua própria vida. Por outro lado, a ruindade da morte é menor se ocorrer depois que algum investimento tiver sido substancialmente concretizado, ou tanto quanto poderia ter sido.

A Resposta Simples supõe que para determinar quanto a morte de alguém foi ruim basta indicar quanto sua vida como um todo teria sido boa se ele não tivesse morrido. A Resposta Complexa exige que se analise a quantidade de investimento humano que foi feito. McMahan (2002, p. 184) sugere que para determinar a ruindade da morte de alguém é preciso analisar os seguintes fatores:

(1) vida em expectativa: quantas coisas boas ele perdeu? (a Resposta Simples)

(2) conexão psicológica: havia conexão psicológica entre ele no momento de sua morte e no momento em que experimentaria as coisas boas de seu futuro? 
(3) normalidade: a quantidade de coisas boas que ele viveu antes de morrer está acima ou abaixo do normal para pessoas com capacidades psicológicas semelhantes às suas?

(4) estrutura narrativa: sua vida tinha uma estrutura narrativa que teria sido completada pela vida futura da qual a morte o privou?

(5) esforço: ele fez investimentos significativos em seu próprio futuro que foram inúteis ou ficaram sem sentido por causa da morte?

(6) mérito: as ações anteriores e o caráter do indivíduo o tornaram merecedor dos bens futuros que ele deixou de ganhar?

(7) desejo: o indivíduo desejava os bens dos quais foi privado quando de sua morte?

Os fatores (2) a (7) são captados pela Resposta Complexa, mas não pela Resposta Simples. São esses fatores que explicam porque mesmo a morte de um centenário é lamentável e porque a morte de um feto de sete meses é pior que a de um feto de dois meses. Dessa maneira, a Resposta Complexa, explica porque o tempo de vida mais curto do adulto vale mais do que o tempo de vida mais longo do feto, isto é, porque (1) está submetido a outras variáveis.

De acordo com esses fatores, a morte é pior na medida em que: a quantidade de coisas boas perdidas é grande; a conexão psicológica do indivíduo com seu futuro teria sido grande (isto é, ele já era capaz de pensar em seu futuro e não possuía problemas de memória); até então o indivíduo havia vivido poucas coisas boas; era de se esperar que a vida futura da vítima levasse a história de sua vida a um estado de completude satisfatório; a vítima havia investido esforços consideráveis se preparando para o futuro que perdeu; a vítima merecia as coisas boas que sua vida futura lhe daria; a maioria das coisas boas que a vida futura da vítima teria eram desejadas por ela no momento de sua morte.

Em contrapartida, uma morte é "menos ruim" na medida em que ela acontece em uma idade muito avançada, quando há pouca perspectiva de coisas boas, quando a demência separou a pessoa atual de seu passado, mas ao final de uma vida de grandes realizações, uma vida em que os esforços da pessoa foram recompensados com sucesso, seus desejos e ambições foram satisfeitos e seus merecimentos respondidos. Enfim, uma vida bem vivida, ricamente integrada, satisfatória, bem sucedida e que culmina em uma velhice serena, tão completa a ponto de haver pouco mais a ser desejado (MCMAHAN, 2002, p. 184). 
Esse conjunto de fatores que compõem a Resposta Complexa indica porque a morte de um feto ou recém-nascido apesar de muito trágica, não é tão lamentável quanto a de um jovem. Embora a perda seja grande porque a vítima tenha recebido muito pouco da vida e por causa dos efeitos nos familiares e amigos, ela é menor porque lhe faltam conexões psicológicas com a vida que ele teria, por causa da ausência de narrativa estrutural na vida, ausência de investimento no futuro, ausência de esforços que justifiquem o merecimento e ausência de desejos específicos por coisas boas futuras. A ruindade da perda deve sofrer os descontos suscitados pela ausência de cada um desses fatores. Já no caso do adolescente, as conexões, o investimento, a narrativa, o merecimento e o desejo normalmente estão em seu máximo.

Portanto, a ruindade da morte varia segundo diversos fatores, mas que estão fortemente correlacionados com a idade - o que explica o apelo intuitivo da Resposta Simples. Eis como esse processo pode ser resumido:

Quando o indivíduo começa a existir, a quantidade de coisas boas a esperar está em seu máximo; mas as relações de unidade prudencial [a capacidade do indivíduo de se enxergar como algo que continua no tempo] que o ligam a seu próprio futuro são tão fracas quanto compatíveis com a identidade. Essa fraqueza diminui muito a força de seu interesse temporalizado [os interesses dos quais o indivíduo tem consciência no momento] em continuar vivo. À medida que o indivíduo se desenvolve psicologicamente, ele se torna cada vez mais relacionado consigo mesmo no futuro das maneiras que importam. Porque a qualidade de vida no útero e nos meses iniciais de vida pós-natal é bastante baixa, a quantidade de coisas boas a esperar se mantém mais ou menos constante durante esse período. Mas esse é um período em que as relações de unidade prudencial ganham força com grande rapidez. Através desse período, e adentrando bastante na infância, parece que o efeito desse fortalecimento das relações de unidade prudencial no interesse temporalizado em continuar vivo excede em muito o efeito da diminuição da quantidade de coisas boas a esperar. Assim, o interesse temporalizado em continuar vivo ganha força constantemente e a ruindade da morte aumenta dramaticamente, através dos primeiros meses e da infância. Quando a infância se torna adolescência, a quantidade de coisas boas a esperar constantemente cai, embora isso continue a ser mais do que contrabalanceado pelo aumento na integração psicológica, unidade narrativa, o número e intensidade dos desejos e ambições do indivíduo e os investimentos que ele faz para satisfazê-los. Exatamente onde fica o pico, e se esse pico é um platô, são questões difíceis de responder com confiança. Obviamente, há variação de indivíduo para indivíduo. E certamente pode ser defendido que esse pico aconteça até mesmo antes da adolescência. Porém, é claro que depois dela, ou no começo da maturidade, quando as capacidades psicológicas do indivíduo estão completamente desenvolvidas e as relações de unidade prudencial atingem sua força total, a ruindade da morte declina lenta, mas continuamente com a idade, na medida em que a quantidade de coisas boas a esperar da vida diminui. Se a velhice traz um declínio nas capacidades psicológicas do indivíduo e um consequente enfraquecimento das relações de unidade prudencial, isso acelerará a diminuição da ruindade da morte. Eventualmente, será atingido um ponto em que a morte dificilmente ainda será um azar (MCMAHAN, 2002, p. 184-185 - tradução minha). ${ }^{3}$ 


\section{O fato de que embriões tenham valor intrínseco poderia justificar uma objeção forte a matá-los?}

A essa altura já deve ser evidente o que essa explicação do que faz a morte de alguém ser ruim implica para a discussão sobre se é errado ou não matar embriões. Certamente o embrião tem muito tempo de vida em expectativa e, portanto, é razoável esperar que o futuro dele contenha muitas coisas boas. Em nenhum momento, inclusive, há tanta vida por vir quanto quando o zigoto se forma, se é que aí já se pode contar um novo ser humano. Mas isso não faz com que a morte de um embrião seja considerada pior do que a de um centenário, de uma mulher de meia idade, de um adolescente, de uma criança, um bebê, um recém-nascido ou de um feto nos estágios finais de gravidez. Na verdade, é de se esperar que até mesmo os concepcionistas considerem a morte do embrião a "menos ruim".

Inclusive, como aponta Mcmahan na citação acima, dado que a qualidade de vida no útero não é das mais ricas em experiência e variedade, é razoável supor que a quantidade de coisas por vir se mantém mais ou menos constante da fertilização até o nascimento, senão até os primeiros meses depois dele, pois o que acontece nesse intervalo não pode ser plausivelmente contado como "coisas boas" no sentido em que normalmente usamos a expressão.

Não há nenhum tipo de relação de conectividade psicológica entre o embrião e a pessoa que ele seria, pois o embrião não tinha desejos, muito menos desejos que perdurariam, nem ninguém tem memória de sua vida enquanto embrião. É como se o futuro do embrião pertencesse à outra pessoa. Visto da perspectiva do adulto, é como se quando ele era um embrião, ele fosse outra coisa ou não fosse nada. Por isso, a ruindade da morte do embrião está entre a ruindade da morte de uma pessoa e a ruindade de uma pessoa nunca existir, a não-concepção (MCMAHAN, 2002, p. 171). Na não-concepção há uma enorme perda de bem futuro possível, mas não há vítima da perda, pois o bem é perdido justamente porque a vítima não existe. É uma perda completamente impessoal. Isso é que faz com que a perda valha menos, ou não valha nada. Uma perda é moralmente sem significado se não há alguém que sofre a perda. Quando uma pessoa morre há a perda de coisas boas que seriam vividas no futuro e há alguém que estaria psicologicamente relacionado ao recipiente daquele bem.

A morte do embrião, obviamente, também não implica a interrupção de uma narrativa de vida, porque essa história não começou, pois nada nela foi consciente. Como diz McMahan, "se 
tudo que se tem são as palavras 'era uma vez...' não se tem uma estória que termina mal; na verdade, não se tem estória nenhuma" (MCMAHAN, 2002, p. 176 - tradução minha). ${ }^{4}$

$\mathrm{O}$ embrião não fez nenhum investimento em sua vida que teria sido tornado inútil por causa de uma morte prematura. Os esforços biológicos não podem ser contados, porque não possuíam intenção, propósito. Deixando de lado o nível meramente biológico e a idéia da inocência das crianças (pois o embrião não é uma criança), o embrião não fez por merecer os bens que seu futuro lhe reservaria, no mesmo sentido que um bom pai de família fez por merecer ver seus filhos crescerem. Portanto, essa consideração que aumentaria a gravidade de sua morte, não lhe está disponível.

Como o embrião, por não ter nenhum tipo de célula diferenciada - muito menos uma célula nervosa, menos ainda um cérebro - é incapaz de ter autoconsciência, ele não pode pensar em seu futuro e por isso não pode desejar nada, muito menos seus bens futuros. Por isso, também essa consideração não the favorece.

Embora o embrião possua, no sentido demográfico, mais expectativa de futuro do que os adultos, seu interesse em continuar vivo deve ser descontado porque lhe faltam todas essas outras características. Feitos todos os descontos, ou o embrião não tem interesse em continuar vivo ou ele é muito próximo de zero. Por isso, McMahan diz que antes da $22^{\mathrm{a}}$ semana o feto é um organismo desocupado, pois não há alguém ali (MCMAHAN, 2002, p. 267-269).

A única coisa que há para lamentar na morte do embrião é o fato de que uma pessoa a mais poderia ter existido. Isso, porém, é mais próximo do que há para lamentar pela perda de gametas do que pela morte de recém-nascidos. No que se refere à "vítima", a morte de um embrião é mais próxima da não-concepção do que do assassinato.

\section{Um problema a mais com o argumento}

Uma última objeção contra o Argumento do Valor Intrínseco é que não é o fato de que a vida humana possua esse valor que faz com que seja errado matar um ser humano adulto. Se o conteúdo da noção de valor intrínseco implica que devam existir graus desse valor, uma métrica do desrespeito, a medida de quanto valor impessoal uma vida tem depende de quanto investimento natural ou humano foi feito nela. Pode ser que aconteça uma situação em que seja preciso escolher entre duas coisas que possuam valor impessoal. Nesse caso, não havendo outros 
critérios que tenham predominância sobre esse tipo de valor, deve ser escolhida a vida que o possua em maior grau, que vem a ser aquela que recebeu mais investimento. Um caso paradigmático é o aborto para salvar a vida da mãe em gestações de alto risco. Nesse caso, segundo o Argumento do Valor Intrínseco, devemos salvar a mãe e não o feto, ainda que ele tenha nove meses, porque o investimento feito pela natureza, pelas outras pessoas e pela própria pessoa é indubitavelmente maior no caso da mãe do que do filho, até mesmo em um caso em que ela tenha 12 anos e sofra de deficiências mentais.

Contudo, se isso é verdade, se aplicaria também à escolha entre vidas de adultos. Seria aceitável defender a vida de certa pessoa em detrimento de outra porque ela recebeu mais investimento. Ou seria aceitável, por exemplo, que se matasse uma pessoa para usar seus órgãos para salvar a vida de duas pessoas. Suponha que nessa situação, as três pessoas em questão tenham a mesma idade, nível psicológico, responsabilidade, talentos, méritos e quaisquer outras características relevantes. Certamente, nesse caso duas vidas têm mais valor impessoal do que uma vida. O que torna errado matar o potencial doador?

A resposta padrão é que as pessoas, pelo fato de possuírem autoconsciência, racionalidade e autonomia, não podem ser computadas em cálculos de utilidade. É o que se chama de dignidade ou valor moral. A dignidade estabelece a Tese do Erro Igual: acima de certo patamar, a morte de qualquer pessoa é igualmente grave, não importa o nível de investimento recebido ou as capacidades psicológicas que possui (MCMAHAN, 2002, p. 235 e 338). Isso está em evidente contradição com a idéia de que há graus de valor intrínseco (que é necessária para explicar porque o aborto tardio é pior do que o aborto inicial).

Para alguns pesquisadores, a moralidade é dividida em duas camadas: a moralidade dos interesses e a moralidade do respeito (MCMAHAN, 2002, p. 245-246). Na moralidade dos interesses entram todos os seres capazes de sentir prazer e dor (p.ex., o feto a partir da $22^{\mathrm{a}}$ semana). Ela é regida pelo Princípio da Utilidade, segundo o qual a ação correta é aquela que produz mais bem-estar (mais prazer ou felicidade e menos sofrimento). Nessa categoria, estão quase todos os animais. Por isso, é moralmente razoável matar um elefante para salvar a vida de dois elefantes, que sejam semelhantes nos aspectos relevantes. Por isso, o aborto de um feto de 7 meses é mais grave do que o de 2 meses. Por isso também, é aceitável matar o feto de 9 meses para salvar a vida da mãe. 
A segunda camada da moralidade é povoada por aqueles seres que além de sentir prazer e dor, são pessoas - capazes de reconhecer e oferecer razões (racionalidade), de se perceberem como contínuos no tempo e no espaço (autoconsciência) e de tomar decisões baseando-se em suas próprias crenças e valores (autonomia) (MCMAHAN, 2002, p. 251-265). O que divide as duas moralidades é o Patamar do Respeito, o limiar que divide entre quem é e quem não é pessoa. Há uma grande área cinzenta entre recém-nascidos (ainda não pessoas) e crianças de três anos (já pessoas), entre primatas superiores e seres humanos adultos típicos e entre portadores de deficiência mental grave e seres humanos adultos típicos. Deixando de lado a controvérsia em torno desses casos, o que interessa é que é razoável supor que todo aquele que esteja acima do Patamar do Respeito está sob a Tese do Erro Igual, isto é, sempre é igualmente errado matar uma pessoa.

Se a Tese do Erro Igual é aceita - e ela é amplamente aceita - esse critério de porquê é errado matar um adulto tem predominância sobre o valor intrínseco. Se o valor intrínseco estiver submetido a esse critério, não é esse valor que explica porquê é errado matar uma pessoa. Pode até ser que o valor impessoal desempenhe algum papel na proibição de matar seres humanos adultos, mas ele é secundário. Desse modo, como esse tipo valor da vida humana não é o fator decisivo, é lícito concluir que ele é pequeno.

\section{Conclusão}

Por tudo isso, mesmo supondo que seja legítimo falar em valor intrínseco da vida e que a vida do embrião humano tenha mais valor intrínseco que a vida de um animal não-humano adulto, se levarmos em conta os fatores que a Resposta Complexa indica como marcadores da ruindade pessoal e impessoal da morte, o fato de que embriões tenham algum valor intrínseco não poderia justificar uma objeção forte a matá-los, pois pouco investimento foi feito neles e nenhum investimento foi feito por eles próprios. Se o descarte desses embriões é necessário para salvar vidas ou torná-las saudáveis (usando células-tronco) ou mesmo para tornar vidas saudáveis possíveis (usando fertilização in vitro), o valor impessoal que essas vidas podem ter não é suficiente para pender a balança moral para seu lado.

Voltando à pergunta feita: no caso dos embriões humanos, qual é o valor intrínseco quando o valor pessoal e o valor instrumental são nulos? A conclusão é que, supondo que ele 
exista, esse valor é insignificante porque não é específico da vida humana já que, partindo da ideia de que o valor intrínseco derivaria do investimento feito na vida, faz sentido pensar que animais não-humanos também o possuiriam. Além disso, dada as especificidades da constituição do embrião, é justo supor que esse valor seria muito pequeno, pois ele não pontua muito nos fatores (2) a (7) da Resposta Complexa sobre a ruindade da morte. Por fim, é de se suspeitar que qualquer que seja o valor intrínseco do embrião, ele não deve ser decisivo, pois ele não é o que torna errado matar pessoas adultas. De acordo com a teoria da moralidade de duas camadas, o que torna errado matar as pessoas adultas é a desconsideração de seus interesses e o desrespeito à sua dignidade (dada por sua racionalidade, autonomia e autoconsciência), sendo que o embrião antes dos 14 dias não pode ser incluído em nenhuma dessas camadas (MCMAHAN, 2007). 


\begin{abstract}
Notas
${ }^{1}$ Licenciado, mestre e doutor em filosofia pela UFMG.

${ }^{2}$ Há intensa discussão na literatura especializada sobre a plausibilidade da noção de valor intrínseco. Esse problema não será tratado aqui, pois nos distanciaria da discussão principal. Os interessados podem consultar (ZIMMERMAN, 2007). No decorrer do texto, valor intrínseco e valor impessoal serão tratados como sinônimos.
\end{abstract}

3 "When an individual first begins to exist, the amount of good in prospect is at its maximum; but the prudential unity relations binding that individual to his own future are about as weak as is compatible with identity. The weakness of these relations greatly diminishes the strength of his time-relative interest in continuing to live. As the individual develops psychologically, he becomes increasingly closely related to himself in the future in the ways that matter. Because the quality of life in utero and in the initial months of postnatal existence is arguably quite low, the amount of good in prospect remains more or less constant during this period. But this is a period in which the prudential unity relations gain in strength with great rapidity. Throughout this period and well into childhood, it seems that the effect of this strengthening of the prudential unity relations on the strength of the individual's timerelative interest in continuing to live greatly exceeds the effect of the diminution of the amount of good in prospect. Hence the individual's time-relative interest in continuing to live gains steadily in strength, and the badness of death increases dramatically, throughout infancy and early childhood. As childhood passes into adolescence, the amount of good remaining in the life steadily declines, though this continues to be more than offset by increases in psychological integration, narrative unity, the number and intensity of the individual's desires and ambitions, and the investments he makes in order to fulfill them. Exactly where the peak is, and whether the peak is actually a plateau, are questions that it is difficult to answer with confidence. There is surely some variation from individual to individual. And there is certainly a case to be made for the view that the peak comes even before adolescence. But it is clear that, after late adolescence or early adulthood, when an individual's psychological capacities are fully developed and the prudential unity relations reach their full strength, the badness of death slowly but steadily declines with age, as the amount of good remaining in the life decreases. If old age brings a decline in an individual's psychological capacities, and a consequent weakening of the prudential unity relations, the pace at which the badness of death diminishes with age will accelerate. Eventually a point will be reached at which death will scarcely be a misfortune at all” (McMAHAN, 2002, p. 184-185).

4 "If all we have are the words, 'Once upon a time . . .,' we do not have a story that ends badly; we do not have a story at all” (MCMAHAN, 2002, 176). 


\section{Referências Bibliográficas}

BOONIN, David. A defense of abortion. Cambridge: Cambridge University Press, 2003.

BIRCHAL, Telma; FRIAS, Lincoln. Aborto de fetos anencéfalos. Ethic@, vol. 8, n. 1, p. 19-30, 2009.

BROWN, Mark. T. The potential of the human embryo. Journal of Medicine and Philosophy, vol. 32, n. 6, p. 585-618, 2007.

DWORKIN, Ronald. Life's dominion - an argument about abortion, euthanasia, and individual freedom. Nova York, Vintage Books, 1993.

FRIAS, Lincoln. A ética do uso e da seleção de embriões. Manuscrito - Tese de Doutorado.

UFMG, 2010. Disponível em: <www.bibliotecadigital.ufmg.br>. Acesso em: 19 de jul. 2011.

HARMAN, Elizabeth. The potentiality problem. Philosophical Studies, vol. 114, n. 1-2, p. 173198, 2003.

HOLLAND, Stephen. Bioethics - a philosophical introduction. Cambridge: Blackwell, 2003.

LIZZA, John P.. Potentiality and human embryos. Bioethics, vol. 21, n. 7, p. 379-385, 2007.

MARQUIS, Don. Why abortion is immoral. The Journal of Philosophy, vol. 86, n. 4, p. 183202, 1989.

Abortion revisited In: STEINBOCK, Bonnie (Org.). The Oxford handbook of bioethics. Oxford: Oxford University Press, p. 395-415, $2007 \mathrm{a}$.

. The moral-principle objection to human embryonic stem cell research. Metaphilosophy, vol. 38, n. 2-3, p. 190-206, 2007 b.

MCMAHAN, Jeff. The ethics of killing: problems at the margins of life. Nova York/Oxford: Oxford University Press, 2002. $189,2007$.

Killing embryos for stem cell research. Metaphilosophy, vol. 38, ns. 2-3, 2007, p. 170-

ZIMMERMAN, Michael. Intrinsic vs. Extrinsic Value. In: ZALTA, Edward N. (Org.). The Stanford encyclopedia of philosophy, 2007. Disponível em: <plato.stanford.edu/archives/ win2009/entries/value-intrinsic-extrinsic >. Acesso em: 15 jul. 2011. 